\title{
KETERAMPILAN MENULIS KALIMAT BAKU OLEH MAHASISWA PGSD SEMESTER IV
}

\author{
Adelina Ginting \\ Program Studi Pendidikan Bahasa Indonesia,FakultasKeguruan dan Ilmu Pendidikan, Universitas Katolik Santo \\ Thomas, Jl. Setia Budi No. 479-F Tanjung Sari Medan - Kode Pos No. 20132
}

\begin{abstract}
Abstrak
Penelitian ini bertujuan mendeskripsikan keterampilan menulis kalimat baku oleh mahasiswa PGSD Semester IV kelas A di UNIKA St. Thomas Medan melalui angket, yang berjumlah 30 mahasiswa. Angket yang menjadi sumber data terdiri 15 buah kalimat dengan memberikan piilhan B (benar) atau S (salah). Hasil yang diperoleh adalah 7 orang memperoleh nilai baik $(23,33 \%), 19$ orang mendapat nilai cukup $(63,3 \%) 4$ orang mendapat nilai kurang baik $(13,33 \%)$
\end{abstract}

\section{Abstract}

This study aims to describe the writing skills of standard sentences by students of PGSD IV Semester A class at UNIKA St. Thomas Medan through a questionnaire, totaling 30 students. Questionnaire which is the source of data consists of 15 sentences by giving piilhan B (true) or S (wrong). The results obtained are 7 people get good grades $(23.33 \%), 19$ people get enough scores $(63.3 \%) 4$ people get poor grades $(13.33 \%)$

Kata Kunci : keterampilan menulis, kalimat baku

\section{Pendahuluan}

\subsection{Latar Belakang}

Bahasa merupakan ungkapan gagasan manusia dengan sistem lambang bunyi atau tanda-tanda lain yang dipakai oleh anggota. Menurut Dardjowidjojo (2003:16) bahasa adalah suatu sistem symbol yang arbitrer yang dipakai oelh anggota masyarakat bahasa untuk berkomunikasi dan berinteraksi antarsesama, berlandaskan pada budaya yang mereka miliki, sedangkan menurut Kridalaksana (1993:2) bahasa adalah sistem lambang bunyi yang arbitrer yang dipergunakan oleh masyarakat untuk bekerjasama, berinteraksi, dan mengidentifikasi diri. Dari definisi di atas dapat disimpulkan bahwa bahasa harus memiliki sistem, berwujud symbol, yang kita lihat, kita denganr dalam lambang, serta bahasa yang digunakan oleh masyarakat dalam berkomunikasi.

Bahasa Indonesia baku adalah bahasa pokok, bahasa utama, bahasa standar, yaitu bahasa yang tunduk pada keteatapan yang telah dibuat dan disepakati bersama mengenai ejaan, tata bahasa kosakata, istilah. Menurut Moeliono (1976:29) mengatakan bahasa baku perlu memiliki sifat kemantapan dinamis, yang berupa kaidah dan aturan yang tetap. Tetapi kemantapan itu cukup terbuka untuk perubahan yang bersistem dibidang kosakata dan peristilahan dan untuk perkembangan 
berjenis ragam dan gaya dibidang kalimat dan makna.

Pengetahuan tentang bahasa Indonesia baku sangat bermanfaat, karena dengan pengetahuan bahasa Indonesia baku seseorang diharapkan dapat menguasai 45 kaidah-kaidah berkomunikasi secara efeketif sesuai dengan tempat dan situasi. Menurut Chaer (1993:52) penggunaan bahasa Indonesia baku dalam situasi resmi, lamaran pekerjaan, karangan ilmiah. Secara lisan, misalnya sebagai bahasa pengantar dalam pendidikan, pidato.

Kata baku adalah kata yang sesuai dengan kaidah-kaidah yang berlaku. Menurut Soedjito (1990:44) kata baku ialah kata yang mengikuti kaidah atau ragam bahasa yang telah ditentukan atau dilazimkan. Pendapat lain mengatakan bahwa kata baku adal;ah kata yang menjadi tolak ukur yang berlaku untuk kuantitas atau kualitas yang ditetapkan berdasarkan kesepakatan (Tim Penyusun Kamus Pusat Pembinaan dan Pengembangan Bahasa, 1992:82). Jadi secara singkat dapat diartikan kata baku adalah kata yang mengikuti kaidah atau ragam bahasa yang etlah ditentukan atau dilazimkan.

Berdasarkan dari beberapa pendapat di atas bahasa baku dan kata baku saling berkaitan hubungan keduanya. Kata baku merupakan kumpulan beberapa huruf yang membentuk kata yang sesuai dengan kaidah yang dilazimkan, sedangkan bahasa baku alat komunikasi dengan tulisam isyarat yang terjadi akibat kumpulan dari beberapa katakata baku yang menghasilkan bahasa komunikasi baku atau yang sesuai dengan kaidah yang dilazimkan, yang dipaki dalam situasi resmi. Dari kata-kata baku membentuk bahasa baku yang dapat digunakan sebagai alat komunikasi secara efektif sesuai dengan tempat dan situasi.

Fungsi bahasa baku adalah sebagai pemersatu segala penutur dari bermacammacam dialek. Dengan bahasa baku ini, bahasa Indonesia memiliki kekhasan yang membedkan dari bahasa lain. Menurut Muslich (1990:6) bahasa baku mengandung tiga fungis yang bersifat pelambang (simbolis), yaitu fungsi pemersatu, pemberi kekhasan, fungsi pembawa kewibawaan, dan satu fungsi bersifat objektif yaitu fungsi yang sebagai kerangka acuan.

Pendapat mengenai bahasa baku juga dikemukakan Moeliono (1988:14) bahasa baku menduduki empat fungsi. Tiga fungsi diantaranya bersifat pelambang atau simbolis, sedangkan yang satu bersifat objektif. Masing-masing diberi nama 1) fungsi pemersatu 2) fungsi pemberi kekhasan 3) fungsi pembawa kewibawaan 4) dan fungsi sebagai kerangka acuan. Dapat disimpulkan bahwa fungsi kata baku adalah bahasa baku menghubungkan semua penutur sebagai dialek bahasa itu. Masing-masing sebagai pemersatu, pemberi kekhasan, kewibawaan dan kerangka acuan. Dengan demikian bahasa baku persatukan penutur menjadi satu masyarakat bahasa dan meningkatkan proses identifikasi penutur seorang dengan penutur lainnya.

Pembelajaran kata baku perlu diberikan kepada mahasiswa agar tidak menimbulkan kesalahan pada mahasiswa dalam mentukan kata baku dan yang tidak baku sehingga dapat mengurangi tingkat tidak paham tentang kata baku. Penggunaan 
bahasa Indonesia oleh lingkungan perkuliaham, masih ditemukan banyak kesalahan. Salah satu penyebab yang paling mendasar bagi mahasiswa sulit memahami kata baku adalah, karena mereka menganggap bahwa kata-kata yang sering dipakai dalam kehidupan sehari-hari adalah benar. Oleh sebab itu, mereka tetap menggunakan kata-kata tersebut walaupun sebenarnya kata-kata itu salah dan tidak sesuai dengan kaidah-kaidah yang ditentukan. Hal demikian itulah yang disebut dengan istilah "salah kaprah". Salah kaparah adalah salah yang sudah umum sehingga tidak terasa lagi kesalahannya (Badudu, 1988:16). Bentuk yang salah kaprah sebaiknya harus segera dikembalikan kepadabentuk yang benar agar tidak terjadi kesalahn-kesalahan yang menyimpang dari kaidah-kaidah yang berlaku.

Tujuan mempelajari bahasa baku adalah agar dapat menggunakan bahasa Indonesia yang baik dan benar. Penggunaan bahasa Indonesia yang baik dan benar, memperoleh pengetahuan tentang kata baku sehingga dapat menerapkan pengetahuan tersebut dalam karangan ilmiah, suratmenyurat resmi, pidato, laporan, dan digunakan dalam situasi belajar mengajar di kelas. Begitu juga halnya dengan sala satu tujuan pengajaran bahasa Indonesia pada semua jenjang pendidikan yang berupaya membimbing anak didik agar mampu menggunakan bahasa Indonesia dalam komnuikasi baik lisan maupun tulisan dengan baik dan benar.

Berdasarkan uraian di atas, maka penulis membahas masalah tentang "Kemampuan Memahami Ketidakbakuan
Kalimat oleh PGSD Semester IV Universitas Katolik Medan". Masalah tersebut dipilih untuk mengetahui kemampuan mahasiswa memahami kalimat baku. Peneliti memilih responden kelas A semester IV.

\subsection{Rumusan Masalah}

Yang menjadi rumusan masalah dal mmakalah ini adlah sebagai berikut

1. Bagaimana kemampuan PGSD Semester IV Kelas A Unika Santo Thomas dalam penulisan kalimat baku?

2. Bagaimana tingkat pemahaman PGSD Semester IV Kelas A Unika Santo Thomas dalam penulisan kalimat baku melalui pemberian angket?

\subsection{Tujuan Penelitian}

1. Untuk megetahui kemampuan PGSD Semester IV Kelas A Unika Santo Thomas dalam penulisan kalimat baku.

2. Untuk mengetahui tingkat pemahaman PGSD Semester IV Kelas A Unika Santo Thomas dalam penulisan kalimat baku melalui pemberian angket.

\subsection{Manfaat Penelitan}

1. Manfaat Teoritis

Untuk menambah khazanah pengetahuan mengenai penulisan dan penggunaan kalimat baku berbahasa khususnya saat menulis. 
2. Manfaat Praktis

a. Bagi Guru

Hasil penelitian ini memberikan gambaran bagi guru tentang penggunaan kalimat baku yang tepat untuk dijadikan pedoman dalam pembelajaran bahasa Indonesia khususnya dalam keterampilan menulis.

b. Bagi Peneliti

Hasil penelitian ini dapat menjadi jawaban dari masalah yang dirumuskan. Selain itu, dengan selesainya penelitian ini diharpakan dapat menjadi motivasi bagi peneliti untuk semakin aktif memberi apresiasi baik itu berupa kritik ataupun saran yang bersifat membangun terhadap siswa/siswi yang belum memahami penulisan kalimat baku.

\section{c. Bagi Pembaca}

Hasil penelitian ini bagi pembaca diharpkan dapat lebih memahami penggunaan dan penulisan kalimat baku khususnya dalam membuat tulisan. Selain itu, diharapkan pembaca semakin jeli dalam memperhatikan penulisan kalimat baku apakah sudah sesuai dengan aturan EYD atau masih belum sessuai dalam sebuah tulisan, jika belum sesuai pembaca hendaknya dapat memperbaiki kesalahan tersebut.

d. Bagi Peneliti yang Lain
Hasil penelitian ini diharapkan dapat memberikan inspirasi maupun bahan pijakan penliti lain untuk melakukan penlitian yang lebih mendalam.

\section{Kajian Kepustakaan}

\subsection{Hakikat Keterampilan Menulis}

\subsubsection{Pengertian Menulis}

Menulis mempunyai peranan yang sangat penting bagi kehidupan manusia. Salah satunya adalah dengan menulis seseorang mengungkapkan gagasan atau pemikiran untuk mencapai maksud dan tujuan tertentu. Menulis merupakan komunikasi yang dilakukan secara tidak langsung atau menggunakan media tulis untuk menyampaikan sesuatau. Menulis merupakan suatu keterampilan berbahasa yang aktif, produktif, kompleks, dan terpadu yang berupa pengungkapan dan yang diwujudkan secara tertulis. Kamus Besar Bahasa Indonesia () "Menulis adalah (1) membuat huruf (angka dan lain sebagainya) dengan pena, pensil, kapur, dan lain sebagainya, (2) melahirkan pikiran atau perasaan (seperti mengarang, membuat surat) dengan tulisan (3) menggambar, melukis (4) membatik (kain).

Dalam komunikasi menulis melibatkan beberapa unsur, yaitu: penulis, isi tulisan, saluran atau media, dan pembaca. Dalman (2014:3) menyatakan bahwa "menulis merpakan suatu kegiatan komunikasi berupa penyampaain pesan (informal) secara tertulis kepada pihak lain dengan menggunakan bahasa tulis sebagai alat atau medianya". 
Hal ini sejalan dengan pendapat Tarigan (2008:3) bahwa "menulis merupakan suatu keterampilan berbahasa yang dipergunakan untuk berkomunikasi secara tidak langsung, tidak secara tatap muka dengan orang lain." Hal ini dapat dipahami bahwa menulis bukan komunikasi satu arah atau tatap muka (face to face) tetapi komunikasi dua arah yang menggunakan perantara.

Menuangkan ide dengan tulisan, menulis tidak ubahnya dengan melukis. Seorang penulis harus berpikir secara kreatif dan logis. Artinya, menulis itu bukan hanya sekedar mencoret-coret kertas tetapi juga butuh kerja otak untuk menuangkan gagasan sehingga jelas dan dipahami oelh pembaca. Suprida (dalam Dalman 2014:5) menulis merupakan suatu proses kreatif yang banyak melibatkan cara berpikikr divergen (menyebar) daripada konvergen (memusat). Menulis memerlukan latihan agar bisa terampil dan efektif dalam melakukannya.

Berdasarkan uraian di atas, dapat disimpulkan bahwa menulis merupakan penyampaian pesan secara tertulis dengan menggunakan media berupa lambanglambang grafik serta dapat dipahami oleh orang lain (pembaca). Keterampilan menulis memerlukan laithan yang konsisten agar tulisan menjadi berkualitas.

\subsubsection{Tujuan Menulis}

Setiap penulis harus mengungkapkan dengan jelas tujuan penulisan yang akan digarapnya. Penulis memiliki tujuan dalam menuangkan pikiran/gagasan dan perasaannya melalui bahasa tulis, baik untuk diri sendiri dan orang lain. Contoh tujuan menulis untuk diri sendiri antara lain agar tidak lupa. Agar rapi, untuk menyusun rencana, dan untuk menata gagasan/pikiran. Bentuk tulisan tersebut dapat dituangkan dalam buku harian, catatan perkuliahan, catatan rapat, catatan khusus, dan sebagainya. Contoh tujuan menulis untuk orang lain antara lain untuk menyampaikan pesan, berita, informasi kepada pembaca, untuk mempengaruhi pandangan pembaca, sebagai dokumen autentik, dan sebagainya.

Tujuan merupakan penentu pokok, pemberi arah, dan pembatas suatu karangan. Menurut Sabarti, dkk (2012:11) mengatakan bahwa "perumusan tujuan penulisan sangat penting dan harus ditentukan lebih dahulu karena hal ini akan menjadi titik tolak dalam seluruh kegiatan menulis tersebut. Dengan mentapkan tujuan penulisan, maka akan mengetahui apa yang kita lakukan pada tahap penulisan, seperti bahan-bahan yang diperlukan, macam organisasi karangan diterapkan, atau sudut pandang yang akan dipilih.

Tarigan (2008:24) menyatakan bahwa "maksud atau tujuan penulis (the writer's intention) adalah response atau jawaban yang diharpkan oleh penulis akan diperolehnya dari pembaca. Berdasarkan batasan ini, dia mengatakan bahwa:

1. Tulisan yang bertujuan untuk memberikan atau mengajar disebut wacana informative (informative discourse)

2. Tujuan yang bertujuan untuk meyakinkan atau mendesak dibseut wacana persuasive (persuasive discourse) 
3. Tulisan yang bertujuan untuk menghibur atau menyenangkan atau yang mengadung unsur estetik disebut tulisan literer (wacana kesastraan atau literary discourse)

4. Tulisan yang mengapresiasi perasaan dan emosi yang kuat atau berapi-api disebut wacana ekspresif (expressive discourse)

5. Mengubah keyakinan pembaca;

Menurut Syafi'ie (1998:51-52) tujuan menulis dapat diklarifikasikan sebagai berikut:

1. Menanamkan pemahaman suatu terhadap pembaca

2. Merangsang proses berpikir pembaca;

3. Menyenangkan atau menghibur pembaca

4. Memberi tahu pembaca

5. Memotivasi pembaca

Berdasarkan penjelasan di atas, dapat disimpulkan bahwa tujuan menulis adalah menjadikan pembaca memahami dan mengerti sesuatu hal yang kita beritakan. Selain itu, melalui tulisan atau karangan terse but si pembaca juga menemukan kesenangan dari tulisan itu dan akhirnya menghayatinya sekaligus menemukan nilainilai, seperti kebenaran, nilai agama, nilai pendidikan moral, nilai kemanusiaan dan nilai estetika (keindahan). Hal-hal yang kita sampaikan melalui tulisan harus komunikatif dan sesuai dengan sasaran tulisan.
Pada prinsipnya fungsi utama menulis adalah sebagai alat komunikasi tidak langsung (Tarigan 1986:23). Darmadi (1996:3) mengemukakan bahwa tulisan memiliki beberapa fungsi penting yaitu:

1. Sebagai suatu sarana menemukan sesuatu

2. Memunculkan ide baru

3. Melatih kemampuan mengorganisasi dan menjernihkan berbagai konsep atau ide yang kita miliki

4. Melatih sikap objektif yang ada pada diri seseorang

5. Mebantu diri kita untuk menyerap dan memproses informasi

6. Melatih kita memecahkan berbagai masalah sekaligus, dan menjadikan kita aktif tidak sekedar menjadi penerima informasi

\subsubsection{Manfaat Menulis}

Menulis memang memiliki kelebihan khusus. Tulisan juga lebih mudah digandakan melalui bantuan tekonologi produksi. Karya-karya tulis memiliki daya bukti yang lebih kuat, selain itu, tulisan memiliki sifat permanen karena dapat disimpan dan lebih mudah diteliti karena dpapt diamati seara perlahan dan berulangulang. Hernowo (2004:51) mengungkapkan bahwa menulis dapat digunakan untuk menyibak atau mengungkapkan diri. Dengan menulis seseorang bukan hanya akan menyehatkan fisik dan mental tetapi juga dapat mengenali detail-detail dirinya.

Sabarti Akhadiah (dalam Kartini 2006:5) manfaat menulis sebagai beriktut:

\subsubsection{Fungsi Menulis}


1. Mengetahui potensi diri dengan dan kemampuan serta pengetahuan kita tentang topic yang dipilih. Dengan mengembangkan topic itu kita dipaksa beripikir, menggali pengetahuan, dan pengalaman yang tersimpan dalam dirii.

2. Dengan mengembangkan berbagai gagasan kita terpaksa bernalar, menghubungkan dan membandingkan fakta-fakta yang tidak pernah kita lakukan kalau kita tidak menulis.

3. Lebih banyak menyerap, mencari, serta menguasai informasi sehubungan dengan topic yang ditulis. Dengan demikian, kegiatan menulis dapat memperluas wawasan baik secara teoritis maupun mengenai fakta-fakta yang berhubungan.

4. Menulis berarti mengorganisasi gagasan secara sistematik serta mengungkapkan secara tersurat. Dengan demikian, setiap permasalahan yang semula samarsamar akan menjadi lebih jelas

5. Melalui tulisan, kita dapat menjadi peninjau dan penilaian gagasan kita secara obyektif.

6. Lebih mudah memecahkan masalah dengan menganalisisnya secara tersurat dalam konteks yang lebih konkrit.

7. Dengan menulis, kita menjadi aktif berpikir sehingga kita dapat menjadi penemu sekaligus pemecah masalah. Bukan hanya sekedar penerima informasi yang pasif.
8. Membiasakan kita berpikir dan berbahasa secara tertib.

Dari beberapa manfaat menulis yang dikemukakan, dapat disimpulkan bahwa menulis bermanfaat untuk mengetahui kemampuan diri dengan aktif berpikir dalam menuangkan ide dan gagasan ke dalam sebuah tulisan, menambah wawasan dan informasi, menumbuhkan keberanian dan kreatifitas. Menulis juga merupakan sarana untuk mengembangkan pemahaman dan kemampuan menggunakan bahasa.

\subsubsection{Ragam Menulis dan Asas Menulis}

Menurut Keraf (1989:6), ragam tulisan didasarkan pada tujuan umum, berdasarkan hal tersebut menulis dapat dibedakan menjadi lima: deskripsi, eksposisi, argumentasi, narasi, persuasi.

1. Deskripsi (perian)

Kata deskripsi berasal dari bahasa latin describere yang berarti menggambarkan atau memberikan suatu hal. Dari segi istilah, deskripsi adalah suatu bentuk karangan yang melukiskan sesuatu sesuai dengan keadaan yang sebenarnya sehingga pembaca dapat mencitrai (melihat, mendengar, mencium dan merasakan) apa yang dilukiskan itu sesuai dengan citra penulisannya.

2. Eksposisi (paparan)

Eksposisi berasal dari kata exposition yang berarti membuka dapat pula diartikan sebagai tulisan yang bertujuan untuk memberitahu, mengupas, menguraikan, atau menerangkan sesuatu 
3. Argumentasi (bahasan)

Yang dimaksud dengan tulisan argumentasi adalah karangan yang terdiri atas paparan alas an dan penyintesisan pendapat untuk membangun suatu kesimpulan. Karangan ini ditulis dengan maksud untuk memberikan alasan, memperkuat atau menolak sesuatu pendapat, pendirian, gagasan.

4. Narasi (kisahan)

Narasi atau naratif adalah tulisan berbentuk karangan yang mnenyajikan serangkaian peristiwa atau kejadian menurut urutan terjadinya (kronologis) dnegan maksud memberi makna kepada sebuah atau rentetan kejadian sehingga pembaca dapat memtik hikmah dari cerita itu.

5. Persuasi

Tulisan yang bermaksud mempengaruhi orang lain dalam persuasi selain logika perasaan juga memegang peranan penting.

\subsection{Hakikat Bahasa Baku Indonesia}

\subsubsection{Pengertian Bahasa Baku Indonesia}

Bahasa Indonesia baku atau disebut juga dengan istilah bahasa stnadar adalah ragam bahasa yang diterima dalam situasi resmi. Bahasa baku digunakan dalam perundangundangan, surat resmi, berbicara di depan umum laporan, karya ilmiah dan digunakan dalam situasi belajar mengajar di kelas. Menurut moeliono (1976:29) mengatakan bahasa Indonesia baku perlu memiliki sifat kemantapan dinamis, yang berupa kaidah dan aturan yang tetap. Tetapi kemantapan itu cukup terbuka untuk perubahan yang bersistem dibidang kosa kata dan peristilahan dan untuk perkembangan berjenis ragam dan gaya dibidang kalimat dan makna.

Badudu (1985:18) menyatakan bahwa bahasa Indonesia baku ialah bahasa pokok, bahasa utama, bahasa standar, yaitu bahasa yang tunduk pada ketetapan yang telah dibuat dan disepakati bersama mengenai ejaan, tata bahasa, kosa kata, istilah. Senada dengan pendapat Suryaman (1995:2) menjelaskan bahasa baku ialah bahasa yang dipakai dalam situasi resmi atau lingkungan resmi, dan pergaulan sopan, seperti dalam surat resmi, karangan, ilmiah, buku-buku pelajaran, pidato, ceramah, pembicaraan dengan orangh yang dihormati atau perlu dihormati dan lain-lain. Wairdah (2008:186), mengungkapkan bahwa bahasa baku adalah ragam bahasa yang cara mengucpkan dan penulisannya sesuai dengan kaidah-kaidah standar, kaidah standar dapat berupa pedoman ejaan (EYD), tata bahasa baku dan kamus umum.

Dari uraian di atas, dapat disimpulkan bahwa bahasa baku atau bahasa standar adalah bahasa yang tunduk pada ketetapan yang telah dibuat dan disepakati bersama mengenai ejaan, tata bahasa, kosakata, dan istilah. Bahasa baku digunakan dalam perundang-undangan, surat resmi, berbicara di depan umum, laporan, karya ilmiah dan digunakan dalam situasi belajar mengajar di kelas.

\subsubsection{Fungsi Bahasa Baku}

Moeliono (1988:14) menyebutkan bahwa bahasa baku mendukung empat fungis tiga diantaranya 
bersifat pelambang atau simbolis, sedangkan yang satu bersifat objektif.

1. Fungsi pemersatu bagi seluruh Indonesia sebagai bahasa nasional, bahasa negara dan bahasa resmi

2. Fungis penanda kepribadian yang dijalankan oleh suatu bahasa bahku dan bahasa yang beradab, akan terlihat jika dipergunakan dalam pergaulan dengan bahasa asing.

3. Fungsi pembawa kewibawaan jika kalangan masyarakat yang berpengaruh menambah kewibawaannya dengan menguasai bahasanya dengan mahir hingga meningkatkan gengsi bahasa Indonesia yang baku itu

4. Fungsi sebagai kerangka acuan yakni ukuran yang disepakati secara umum tentang tepat tidaknya pemakaian bahasa di dalam situasi tertentu

Senada dengan pendapat Muslich (1990:6), bahasa baku mengandung tiga fungsi yaitu bersifat pelambang (simbolis), yaitu pemersatu, pemberi kekhasan, fungsi pembawa kewibawaan, dan satu fungsi yang bersifat objektif yaitu fungsi yang sebagai kerangka acuan. Bahasa baku bisa mempersatukan segala penetur dari bermaca-macam dialek. Dengan bahasa baku ini, bahasa Indonesia memiliki kekhasan yang membedakan dari bahasa lain.

\subsubsection{Ciri-Ciri Bahasa Baku}

Waridah (2008:186) mengatakan bahwa bahasa baku memiliki ciri-ciri berikut ini:

1. Tidak dipengaruhi bahasa daerah

2. Tidak dipengaruhi bahasa asing

3. Bukan merupakan bahasa percakapan

4. Pemakaian imbuhan secara eksplisit

5. Pemakaian yang seusai dengan konteks kalimat

6. Tidak mengandung makna ganda, tidak rancu

7. Tidak mengandung arti peonasme

8. Tidak mengandung hiperkorek

\subsubsection{Ragam Bahasa Baku}

Chaer (2006:4) mengatakan bahwa yang dimaksud dengan bahasa baku adalah salah satu ragam bahasa yang djiadikan pokok, yang diajukan dasar ukuran atau yang dijadikan standar. Ragam bahasa baku ini lazim digunakan dalam:

1. Komunikasi resmi, yakni dalam surat menyurat resmi, surat menyurat dinas, pengumuman yang dikeluarkan oleh instansi resmi, perundang-undangan penamaan dan peristilahan resmi

2. Wacana teknis seperti dalam laporan resmi, karangan ilimiah, buku pelajaran

3. Pembicaraan di depan umum, seperti dalam ceramah, kuliah, pidato

4. Pembicaraan dengan orang yang dihormati 
Pemakaian (1) dan (2) didukung oleh bahasa tertulis, sedangkan pemakaian (3) dan (4) didukung oleh ragam bahasa linsa. Dari empat fungsi bahasa yang menuntut ragam baku itu, hanya dua yang terkahir yang langsung berkaitan dengan komunikasi verbalsecara lisan. Dengan kata lain, lafal baku perlu digunakan dalam pembicaraan di depan umum, seperti kuliah, ceramah, khotbah, pidato, dan sebagainya, atau dalam pembicaraan dengan orang yang dihormati seperti pembicaraan dengan atasan, dengan guru, dengan orang yang baru dikenal.

Di atas telah kita lihat bahwa ragam bahasa baku dianggap sebagai ragam bahasa yang baik dan cocok untuk keperluan komunikasi verbal yang penting, yang menjadi tolok untuk pemakaian bahasa yang benar. Ragam bahas baku itu merupakan ragam bahasa yang standar, bersfiat formal. Ragam bahasa baku biasanya digunakan dalam situasi resmi, seperti acara seminar, pidato, temu karya ilmiah, dan lain-lain (Waridah 2008:186). Ragam bahasa baku adalah kosakata baku bahasa Indonesia, yang memiliki cirri kaidah bahasa Indonesia ragam baku, yang dijadikan tolok ukur yang ditetapkan berdasarkan kepekatan penutur bahasa Indonesia, bukan otoritas lembaga atau instansi di dalam menggunakan bahasa Indonesia ragam baku.

Tuntutan untuk menggunakan ragam bahasa seperti ini biasa ditemukan dalam pertemuan-pertemuan yang bersifat formal, misalnya dalam tulisan-tulisan ilmiah seperti makalah, skripsi, tesis, dan disertasi, percakapan dengan yang berstatus akademis yang lebih tinggi, dan sebagainya. Bagi dunia periklanan, misalnya, ragam bahasa yang dianggap baku ialah bahasa yang lebih bersifat menjual;selama bersifat menjual, bakulah bahasa mereka meskipun kalau ditilik secara preskriptif pastilah tidak tepat. Sedangkan bagi kalangan penerbiatam gaya selingkung mereka merupakan standar kabkuan yang tidak boleh tidak diikuti oleh para editornya, karena dengan demikian mereka menjaga konsistensinya, terlepas dari perkembangan kebakuan yang dirumuskan oleh pihak Pusat Bahasa. Demikian pula, bagi kalangan anak muda atau remaja-remaja saat ini, bahasa gaul menjadi ragam bahasa baku mereka sendiri.

\subsubsection{Pengertian Kata Baku}

Kata baku adalah kata yang standar sesuai dengan aturan kebahasaan yang belaku, didasrakan atas kajian berbagai ilmu, termasuk ilmu bahasa dan sesuai dengan perkembangan zaman. Kebakuan kata sangat ditentukan oleh tinjauan disiplin ilmu bahasa dari berbagai segi yang ujungnya menghasilkan satuan bunyi sangat berarti sesuai dengan konsep yang disepakati. Soedjito (1988:44) berpendapat bahwa kata baku adalah kata yang mengikuti kaidah atau ragam bahasa yang telah ditentukan akan dilazimkan. Bila berpedoman pada sistem tersbut akan terlihat keberaturan dan kemantapan bahasa Indoensia. Berdasarkan kutipan di atas kata baku sebenarnya merupakan kata yang digunakan sesuai dengan kaidah bahas Indonesia yang telah ditentukan. Konteks penggunaannya adalah dalam kalimat resmi, baik lisan maupun tertulis dengan pengungkapan gagasan secara tepat.

Chaer (200:6) mengatakan bahwa kata baku adlah kata yang mengikuti kaidah 
bahasa yang telah ditentukan. Maksudnya, kata-kata yang digunakan adalah kata-kata umum yang sudah lazim digunakan atau yang frekuensi penggunannya cukup tinggi. Kata-kata yang lazim atau masih bersifat kedaerahan sebaiknya tidak digunakan, kecuali dengan pertimbangan-pertimbangan khusus.

Jadi secara singkat dapat disimpulkan kata baku adalah kata yang mengikuti kaidah atau ragam bahasa yang telah ditentukan atau dilazimkan. Kata yang standar resmi dengan aturan kebahasaan yang berlaku, didasarkan atas kajian berbagai ilmum termasuk ilmu bahasa dan sesuai dengan perkembangan zaman.

Dalam bahasa Indonesia hanya ada satu bentuk yang dianggap baku, yang lain adalah bentuk nonbaku. Bentuk baku biasanya digunakan dalam situasi resmi. Pemakaian bahasa sering tidak memahami bentuk yang baku dan bentuk yang nonbaku. Baku atau tidaknya suatua kata antara lain ditentukan oleh 1) perbedaan ejaan, seperti azas-asas, praktek-praktik, 2) adanya sifat kedaerahan, seperti imbuh-tambah, 3) adanya tata bentuk kata, seperti merubahmengubah. Kebakuan kata amat ditentukan oleh tinjauan disiplin ilmu bahasa dari berbagai segi yang ujungnya menghasilkan satuan bunyi yang amat berarti sesuai dengan konsep yang disepakati terbetnuk. Kata baku dalam bahasa Indonesia berpedoman pada Pedoman Umum Pembentukan Istilah yang telah ditetapkan oleh Pusat Pembinaan dan Pengembangan Bahasa bersamaan ditetapkannya pedoman sistem penulisan dalam Ejaan Yang Disempurnakan.
Menurut Triningsih (2009:17) kata baku digunakan dalam hal-hal berikut

1. Komunikasi resmi misalnya, suratmenyurat resmi, dokumen pemerintahan atau pemberitahuan yang sifatnya resmi

2. Wacana resmi misalnya, laporan ilmiah, karya ilmiah, atau tulisan yang bersifat resmi

3. Pembicaraan di depan umum misalnya pidato, ceramah, atau mengajar

4. Pembicaraan yang bersifat resmi dengan orang yang dihormati

Perhatikan contoh:

\begin{tabular}{|l|l|}
\hline Kata Baku & Kata Tidak Baku \\
\hline Senin & Senen \\
\hline AKhir & Akir \\
\hline Kuitansi & Kwitansi \\
\hline Pihak & Fihak \\
\hline Sistem & Systim \\
\hline Ijazah & Ijasah \\
\hline
\end{tabular}

\section{Metode Penelitan}

\subsection{Jenis Penelitian}

Jenis penelitian yang diterapkan pada laporan hasil penelitian ini adalah jenis penelitian kuantitatif-kualitatif. Jenis penelitian tersebut dipilih karena jangka waktu yang dimiliki oleh penulis hanya sebentar sehingga tidak memungkinkan untuk menerapkan jenis penelitian kualitatif.

\subsection{Objek Penelitian}


Yang menjadi objek penelitian ini adalah Mahasiswa PGSD Semester IV Kelas A Unika Santo Thomas tahun 2017 yang terdiri dari 34 orang.

\subsection{Metode Pengumpulan Data}

Metode penelitian adalah cara yang dilakukan untuk mencapai tujuan penelitian. Makin tepat metode yang digunakan makin baik pula hasil yang didapatkan. Arikunto (2016:22) mengemukakan bahwa metode penelitain merupakan struktur yang sangat penting, karena berhasil tidaknya dan rendahnya kualitas hasil penelitian sangat ditentukan oleh ketetapan dalam memilih metode penelitian.

Metode yang dilakukan dalam penelitian ini adalh sebagai berikut:

1. Metode kuisioner/pembagaian angket, yaitu dilakukan dengan cara memberikan angket kepada Mahasiswa PGSD Smeseter IV Kelas A Unika Santo Thomas tahun 2017 yang terdiri dari 30 orang yang di dalamnya berupa soal atau sejumlah tes tertulis mengenai penulisan kalimat baku

2. Metode Studi Pustaka, yaitu berupa kajian literature yang sesuai dengan penelitian baik berupa buku, majlaah maupun dari sumber internet.

\subsection{Hasil Penelitian dan Pembahasan}

Dari hasil penelitian berdasarkan angket tentang penulisan umur partikel yang telah diberikan kepada mahasiswa prodi
PGSD Semester IV Kelas A Unika Santo Thomas sebagai objek penelitian yang berjumlah 30 orang bahwa dari hasil angket tersebut di peroleh nilai sebagai berikut.

\section{Petunjuk Kerja:}

Berilah tanda centang $(\checkmark)$ pada kolom "B", jika menurut Anda pernyataan itu benar dan kolom "S", jika menurut Anda pernyataan itu salah.

\begin{tabular}{|c|c|c|c|}
\hline $\mathrm{NO}$ & KALIMAT & Benar & Salah \\
\hline 1 & $\begin{array}{l}\text { Bagi yang membawa } \\
\text { telepon genggam } \\
\text { harap dimatikan! }\end{array}$ & & \\
\hline 2 & $\begin{array}{l}\text { Para mahasiswa saling } \\
\text { dorong-mendorong } \\
\text { untuk memasuki kelas. }\end{array}$ & & \\
\hline 3 & $\begin{array}{l}\text { Kenaikan harga BBM } \\
\text { cukup menyulitkan } \\
\text { rakyat. }\end{array}$ & & \\
\hline 4 & $\begin{array}{l}\text { Budi membelikan baju } \\
\text { adiknya. }\end{array}$ & & \\
\hline 5 & $\begin{array}{l}\text { Dia ngontrak rumah di } \\
\text { Gedung lama. }\end{array}$ & & \\
\hline 6 & $\begin{array}{l}\text { Motor paman saya } \\
\text { baru. }\end{array}$ & & \\
\hline 7 & $\begin{array}{l}\text { Mereka saling ejek- } \\
\text { mengejek }\end{array}$ & & \\
\hline 8 & $\begin{array}{l}\text { Guru saya, Pak } \\
\text { Bambang, pandai } \\
\text { sekali. }\end{array}$ & & \\
\hline 9 & $\begin{array}{l}\text { Saya sudah terima } \\
\text { hadiahmu. }\end{array}$ & & \\
\hline 10 & $\begin{array}{l}\text { Kalian semua } \\
\text { dipersilahkan untuk } \\
\text { pulang. }\end{array}$ & & \\
\hline 11 & $\begin{array}{l}\text { Ibu saya biru } \\
\text { lemarinya }\end{array}$ & & \\
\hline 12 & $\begin{array}{l}\text { Husni mundur ke } \\
\text { belakang dan } \\
\text { mengambil sapu. }\end{array}$ & & \\
\hline 13 & $\begin{array}{l}\text { Saya sudah terima } \\
\text { paketmu. }\end{array}$ & & \\
\hline
\end{tabular}




\begin{tabular}{|l|l|l|l|}
\hline 14 & $\begin{array}{l}\text { Kalian dipersilahkan } \\
\text { ke perpustakaan. }\end{array}$ & & \\
\hline 15 & $\begin{array}{l}\text { Dalam masyarakat } \\
\text { Yogyakarta mengenal } \\
\text { tradisi Sekatenan }\end{array}$ & & \\
\hline
\end{tabular}

Nilai Akhir $=\frac{\text { Skor yang diperoleh }}{\text { Skor maksimal }} \times 100$

\begin{tabular}{|l|c|c|}
\hline NO & Jumlah Siswa & Nilai \\
\hline 1 & 2 & 73.33 \\
\hline 2 & 5 & 71 \\
\hline 3 & 6 & 64,50 \\
\hline 4 & 6 & 63,33 \\
\hline 5 & 7 & 60,66 \\
\hline 6 & 3 & 55 \\
\hline 7 & 1 & 50 \\
\hline
\end{tabular}

\section{Keterangan Tabel:}

Yang memperoleh nilai tertinggi ada 2 orang yaitu memperoleh nilai 73,33 yang memperoleh nilai 66,66 ada 5 orang, nilai 60 ada 6 orang, nilai 53,33 ada 6 orang dan nilai 46,66 ada 7 orang, nilai 33,33 ada 1 . Jumlah siswa seluruhya 30.

Konversi/rentang nilai

\begin{tabular}{|l|l|l|}
\hline Interval Nilai & Kategori & Makna \\
\hline $81-100$ & A & Sangat Baik \\
\hline $71-80$ & B & Baik \\
\hline $61-70$ & C & Cukup Baik \\
\hline $51-60$ & D & Kurang Baik \\
\hline $0-49$ & E & $\begin{array}{l}\text { Buruk/sangat } \\
\text { tidak baik }\end{array}$ \\
\hline
\end{tabular}

Dari rentang niliai di atas, dapat diketahui nilai yang diperoleh mahasiswa PGSD Semester IV kelas A Unika Santo Thomas 2017 sebagai berikut:

\begin{tabular}{|l|l|l|}
\hline $\begin{array}{l}\text { Interval } \\
\text { Nilai }\end{array}$ & $\begin{array}{l}\text { Kategori/Jumlah } \\
\text { Siswa }\end{array}$ & Makna \\
\hline $81-100$ & $\mathrm{~A}=0$ siswa & $\begin{array}{l}\text { Sangat } \\
\text { Baik }\end{array}$ \\
\hline $71-80$ & $\mathrm{~B}=7$ siswa & Baik \\
\hline
\end{tabular}

\begin{tabular}{|l|l|l|}
\hline 61-70 & $\mathrm{C}=19$ siswa & $\begin{array}{l}\text { Cukup } \\
\text { Baik }\end{array}$ \\
\hline $51-60$ & $\mathrm{D}=4$ siswa & $\begin{array}{l}\text { Kurang } \\
\text { Baik }\end{array}$ \\
\hline
\end{tabular}

Keterangan:

Dari tabel di atas menunjukkan bahwa mahasiswa PGSD Semester IV kleas A Unika Santo Thomas 2017 tidak ada yang memperoleh nilai yang baik yaitu dengan keategori (A) berjumlah 0 orang, kategori (B) berjumlah 7 orang, kategori (C) berjumlah 19 orang dan kategori (D) berjumlah 4 orang.

Jadi dapat disimpulkan bahwa mahasiswa PGSD Semester IV kelas A Unika Santo Thomas 2017 sebagaian besar sudah memahami tentang penulisan kalimat baku. Oleh karena itu, perlu ditingkatkan pengetahuannya tentang penulisan kalimat baku lagi yang mengerti dan yang belulm memahami tentang penulisan kalimat baku, perlu dilakukan pendekatan atau pengajaran ulang kembali tentang materi penulisan kalimat baku oleh guru mata pelajaran dengan menggunakan metode dan media sesuai dengan kemampuan yang dimiliki siswa dan guru serta mempertibmagkan waktu dan biaya pelaksanannya.

\subsection{Simpulan}

Menulis merupakan kegiatan kebahasaan yang memegan perna penting dalam dinamika perdaban manusia. Dengan menulis seseorang dapat melakukan komnuikasi, mengemukakan pendapat baik dari dalam maupun dari luar dirinya serta mampu memperkaya pengalamannya. Melalui kegiatan menulis pula seseorang dapat mengambil manfaat bagi 
perkembangan dirinya. Keterampilan menulis merupakan urutan yang paling terkahir dalam proses belajar bahwa setelah keterampilan menyimak, berbicara dan membaca. Di antara keempat keterampilan tersebut, yang paling sulit untuk dikuasai adalah keterampilan menulis.

Menulis adalah kegiatan melahirkan pikiran dan perasaan tulisan. Dapat juga diartikan bahwa menulis adalah berkomunikasi mengungkapkan pikiran, perasaan, dan kehendak kepada orang lain secara tertulis. Keterampilan menulis merupakan salah satu aspek keterampilan berbahasa yang harus dikuasai setiap insane, selain ketiga keterampilan lain yaitu membaca, menyimak dan berbicara. Menulis merupakan keterampilan berbahasa yang dipergunakan untuk berkomunikasi secara tidak langsung. Menulis merupakan kegiatan yang produktif dan ekspresif sehingga penulis harus mampu memanfaatkan kemampuan dalam menggunakan tata tulis, struktur bahasa, dan kosakata.

\section{Daftar Pustaka}

Akhadiah, Sabarti dkk. 2012. Pembinaan Kemampuan Menulis Bahasa Indonesia. Jakarta: Erlangga

Arikunto. 2016. Prosedur Penelitian Suatu Pendekatan Praktik. Jakarta: Rineka Cipta

Badudu, J.S. 1988. Inilah Berbahasa yang Benar. Jakarta: PT Gramedia

Badudu, J.S. 1985. Pelik-Pelik Bahasa Indonesia. Bandung: Pustaka Prima
Sesuai dengan hasil temuan di lapangan dan pembahasan hasil angket mahasiswa maka dapat disimpulkan:

1. Kemampuan mahasiswa dalam menulis kalimat baku masih belum memadai, karena hanya 7 orang saja yang mendapat nilai baik $(23,33 \%)$, 19 orang mendapat nilai cukup $(63,3 \%)$ dan 4 orang mendapat nilai kurang baik $(13,33 \%)$

2. Tingkat pemahaman juga masih kurang dalam menulis kalimat baku bahasa Indonesia karena yang harus diperhatikan mulai dari penulisan kata, tanda baca dan struktur gramatikalnya

\subsection{Saran}

Bahasa baku adalah bahasa yang sesuai dengan EYD. Pemakaian bahasa baku harus disesuaikan dengan situasi formal atau resmi, dan menggunakannya secara baik dan benar. Untuk itu, mahasiswa harus mampu menggunakan kalimat baku secara lisan maupun tulisan.

Chaer, Abdul. 1993. Tata Praktis Bahasa Indonesia. Jakarta: Rineka Cipta

Chaer, Abdul. 2006. Tata Bahasa Praktis Bahasa Indonesia. Jakarta: Rineka Cipta

Dalman. 2014. Keterampilan Menulis. Jakarta: PT. Raja Grafindo Persada

Dardjowidjojo, Soedjono. 2003. Psikolinguistik: Pemahaman Bahasa Manusia. Jakarta: Yayasan Obor Indonesia 
Darmadi, Kaswan. 1996. Meningkatkan Kemampuan Menulis. Yogyakarta: Andi Offset

Hernowo. 2004. Self Digesting; Alat Menjelajahi dan Mengurai Diri. Bandung: Mizan Media Utama

Kartini. 2006. Macam-Macam Narasi. Bandung: Rineka Cipta

Keraf, Gorys. 1989. Tata Bahasa Indonesia: Untuk Sekolah Lanjutan Atas. Flores: Nusa Indah

Kridalaksana, Harimurti. 1993. Kamus Linguistik. Jakarta: Gramedia

Moeliono, Anton M. 1976. Kamus Besar Bahasa Indonesia. Jakarta: Balai Pustaka

Moeliono, Anton M. 1988. Kamus Besar Bahasa Indonesia. Jakarta: Bali Pustaka

Muslich, Masnur. 1990. Tata Bentuk Bahasa Indonesia: Kajian Ke Arah Tata Bahasa Deskriptif. Malang: YA3

Soedjito. 1990. Kosakata Bahasa Indonesia. Jakarta: Gramedia

Soedjito. 1988. Kalimat Efektif. Bandung: Remadja Karya (1988:44)

Suryaman, Ukun. 1995. Dasar-Dasar Bahasa Indonesia Baku. Bandung: Alumni

Tarigan, Henry Guntur. 2008. Membaca Sebagai Suatu Keterampilan Berbahasa. Bandung: Angkasa

Tim Penyusun Kamus Pusat Pembinaan dan Pengembangan Bahasa. 1992. Depdikbud
Triningsih, Diah Erna. 2009. Frasa. Klaten: PT. Intan Prawira

Waridah, Ernawati. 2008. EYD dan Seputar Kebahasa-Indoensiaan.

Jakarta:
Kawanpustaka 